\title{
Analysis of the Breeding System and of Chromosome Pairing at Meiosis in a Population of Cenchrus ciliaris L. from District Rawalakot, Azad Kashmir-Pakistan
}

\author{
M. Fareed Khan* and Gareth M. Evans \\ Laboratory of Cytogenetics, Institute of Biological Sciences, University of Wales, \\ Aberystwyth, Dyfed, SY 23 3DD UK
}

Accepted November 28, 1996

The pattern of evolution and the taxonomic relationships between species and genera within the Graminaceae have always been of considerable interest on account of the many commercially important crop species within this group (Hacker 1995). The chromosome numbers and meiotic behaviour have been of particular value in characterising different species (Stebbins 1956, Mehra and Remanandan 1973, Wajahatullah 1994, Neelam and Narayan 1994), together with morphological (Mehra and Anderson 1961) and protein characteristics (Johnson and Hall 1965) and geographical distribution (Hartley 1958).

Several species of agronomic importance belong to the genus Cenchrus, of which Cenchrus ciliaris is the most widely distributed. It has been successfully introduced into the southern United States, and into the sub-tropical area of Australia (Langer and Hill 1982), where it is the most widely used grass (Hutton 1970).

Cenchrus ciliaris, commonly known as buffelgrass is native to West and East Africa, India, Pakistan and Indonesia (Nath et al. 1970), normally found in tropical and sub-tropical regions from sea level to 2,000 m altitude, mostly in dry areas (Whyte et al. 1959). It is a perennial with probably an apomictic mode of reproduction (Brown 1948, Fischer et al. 1954, Snyder et al. 1955, Bray 1978, Sherwood et al. 1980), however, pollination is required for endosperm development.

Chromosome numbers of $2 \mathrm{n}=32$ (Krishnaswamy 1940), 34 (Brown 1948, Darlington and Wylie 1955, Pienaar 1955, Gould 1956, De Lisle 1963) and 36 (Brown 1948, De Wet and Anderson 1956, Gould 1958, Mannetje and Jones 1992) have been reported.

The main use of Cenchrus ciliaris is as a pasture grass for ruminants and though normally grazed, may alsc be used for silage or hay. It is also highly palatable to all kinds of grazing animals (Khan 1970).

The present investigation was designed to confirm the breeding system and check somatic chromosome number, including the salient features of meiotic chromosome behaviour of an indigenous population of Cenchrus ciliaris from District Rawalakot, Azad Kashmir-Pakistan.

\section{Materials and methods}

\section{Plant material}

Seeds of Cenchrus ciliaris were collected from a wild population chiefly distributed in the hills of District Rawalakot, Azad Kashmir-Pakistan. The plants were identified by consulting "Flora of Pakistan" (Cope 1982). Seeds were grown in five inch pots in a greenhouse $\left(20^{\circ} \mathrm{C}\right)$ at the Institute of Biological Sciences, University of Wales, Aberystwyth, UK.

\footnotetext{
* Corresponding author: University College of Agriculture, Rawalakot, Azad Kashmir-Pakistan.
} 


\section{Breeding system}

Cenchrus ciliaris is believed to be apomictic. Both the pollination system and the variability of single plant progeny were examined during this investigation.

\section{Pollination system}

Plants were grown inside the greenhouse in 5 inch pots. Plant inflorescences were bagged before anthesis. At maturity the heads were harvested and threshed separately, in order to compare the seeds harvested from isolated plants with non-isolated ones.

\section{Electrophoresis}

Open pollinated single plant progeny were used for this analysis. Three enzyme systems, Glutamate-Oxaloacetate-Transaminase (GOT), Phospho-Gluco-Isomerase (PGI), and Esterase (EST) were analysed by horizontal starch gel electrophoresis. The enzymes were isolated from the extract obtained by crushing the young leaves in a few drops of cold $0.1 \mathrm{M}$ Tris- $\mathrm{HCl}$ buffer, $\mathrm{pH}$ 7.5. Each extract was absorbed onto small paper wicks which were inserted at intervals into a transverse cut in the gel. Electrophoresis was conducted at $4{ }^{\circ} \mathrm{C}$ at 300 Volts. Gels were stained in appropriate solutions for each of the three enzymes (Evans and Davies 1985). Gels were fixed in 50\% glycerol and the relative positions of each isozyme band noted for each plant.

\section{Cytological preparations}

Mitosis

Mitotic chromosome preparations were made from young root tips collected from vigorous, healthy plants. Chromosomes were arrested at metaphase by pretreating root tips with $0.056 \%$ colchicine solution for $6 \mathrm{hr}$ at room temperature (Wallace and Callow 1995). They were then fixed in $1: 3$ acetic-alcohol fixative for $24 \mathrm{hr}$ at room temperature. The fixed root tips were hydrolysed in $1 \mathrm{~N} \mathrm{HCl}$ at $60^{\circ} \mathrm{C}$ for $12 \mathrm{~min}$ and stained for $2 \mathrm{hr}$ in Feulgen stain and squashed in $2 \%$ aceto-carmine.

\section{Meiosis}

Flower buds containing anthers undergoing meiosis were collected in freshly prepared Carnoy's fluid (6:3:1 absolute alcohol : chloroform : glacial acetic acid). A few drops of ferric chloride were added (Saturated solution) to the fixative. Pollen mother cells (PMCs) were squashed in $2 \%$ aceto-carmine. Chromosome number, chiasmata frequency and chromosome behaviour was recorded.

\section{Results and discussion}

\section{Breeding system}

Plant species exhibit a great diversity of breeding system (Jain 1976), with several modes defined by the origin of uniting gametes, mainly self- and cross-pollination (De Lisle 1963). The potentialities are further effected by population density, the distribution of the floral organs, developmental sequences within flowers and between flowers pollinator activity, and pollen competition. In addition, there are several kinds of asexual or apomictic reproduction (Bashaw 1962, Brown and Emery 1958).

The main aim of this paper was to establish whether this population exhibited an apomictic mode of reproduction as has been previously reported for Cenchrus ciliaris (Brown 1948, Fischer et al. 1954, Snyder et al. 1955, Gould 1956, Nath et al. 1970, Bray 1978, Sherwood et al. 1980).

Apomictic grasses "breed true to type" in that the seed progenies retain the same character- 
istics as the maternal parent. This is the inevitable consequence of the embryo having developed from an unreduced vegetative nucleus. However many apomictics are also pseudogamous in that pollination and fertilisation of the primary endosperm nucleus is required for the successful development of the asexual embryo. Snyder et al. (1955) suggested that Cenchrus ciliaris was not only apomictic but pseudogamous as well.

Homozygous self-pollinating plants also breed true and produce uniform progeny. Consequently in establishing that plants are apomictic, self-pollination must first be ruled out and, moreover, that cross-pollination between different genotypes results in uniform progeny identical with the maternal parent. This is irrespective of whether plants are homozygous or heterozygous. This was indeed established for this population of Cenchrus ciliaris.

\section{Pollination system}

No seed was obtained from single inflorescences bagged prior to anthesis while a high degree of seed production was obtained from open pollinated plants and from "paired crosses". This ruled out self-pollination as part of the breeding system.

\section{Within population and parent/progeny variability}

Isozyme analysis was used to compare genotypes both within the population and between open-pollinated progeny of single plants as well as to compare parent/progeny genotype. Three different enzyme systems, GOT, PGI and Esterase were initially used to classify plants from within the base population. Very little variation between plants was detected for both GOT and PGI, but the Esterase profiles showed significant differences between some plants. A diagram of the Esterase profiles of 10 different parental plants from the base population is given in Fig. 1 .

Esterase profiles of "open-pollinated" progenies of individual "seed" parents were compared with each other and with the maternal parent and with other parents in the base population. In all cases there was complete uniformity within progeny groups and, moreover, the pattern was identical to that of the maternal parent. This is typified by parent 5 and its progeny as shown in Fig. 2. All progeny plants $(\mathrm{a}-\mathrm{g})$ have identical zymograms to each other and to parent 5 but different from others, parents 2 and 3 in this particular example. Uniformity of this type in the progeny of "cross-pollinated" plants where considerable variability exists could only arise through apomixis. Moreover, it is tempting to conclude that this is a facultative apomict as the level of variation within the whole population was higher than

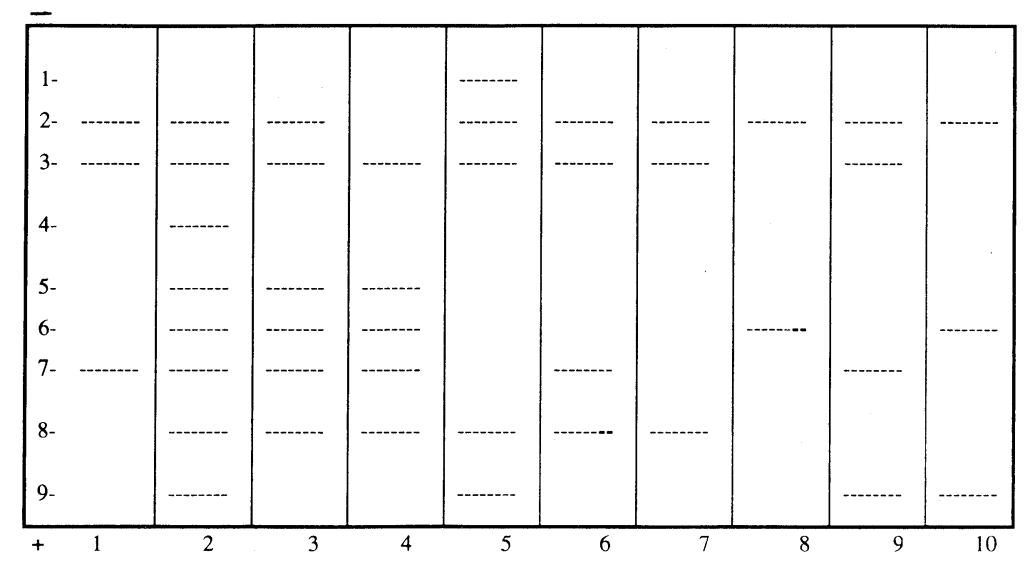

Fig. 1. Schematic presentation of esterase (EST) zymograms of 10 parent plants from the base population. 


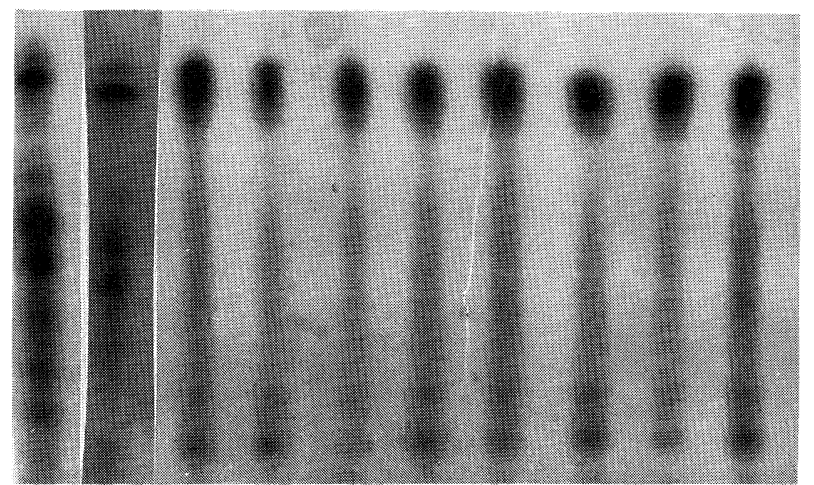

Fig. 2a. Esterase (EST) zymograms of parents 2, 3, 5 and the progeny of parent 5 (a, b, c, d, e, f, g).

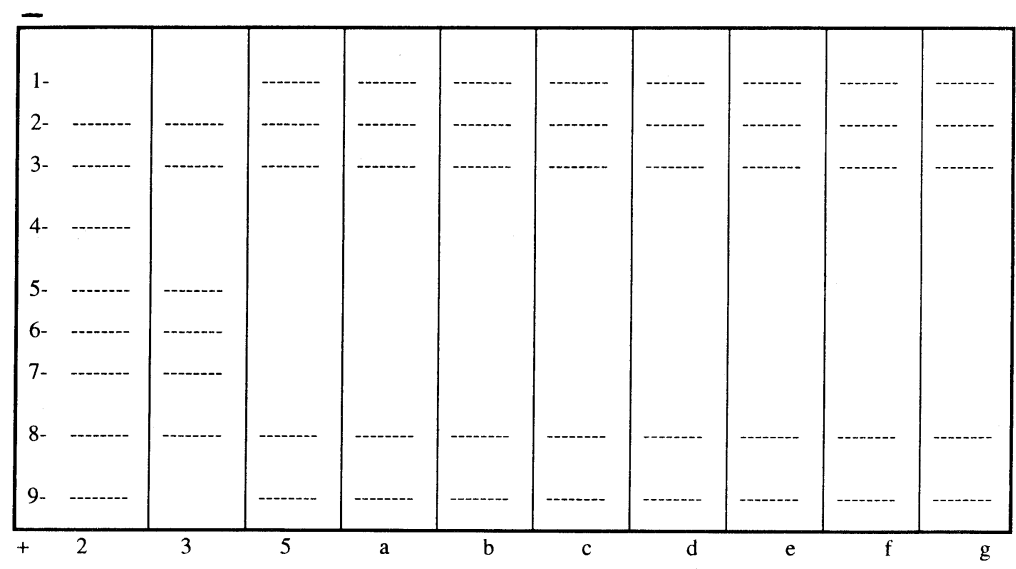

Fig. 2b. Interpretation of zymograms of parents $2,3,5$, and the progeny of parent 5 (a, b, c, d, $\mathrm{e}, \mathrm{f}, \mathrm{g})$.

could be expected from mutation alone.

The result of these experiments indicate that this population of Cenchrus ciliaris from Azad Kashmir-Pakistan is an apomict, probably a facultative apomict. This is in agreement with reports on other populations of this species.

Fischer et al. (1954) conducted extensive cytogenetic studies on many buffelgrass introductions received from Africa and India. Studies of megasporogenesis and embryo sac development in 18 distinct biotypes showed that in all cases the megagametophyte collapsed and nucellar cells took over the function of the megaspore and developed into the female gametophytes. Embryo development occurred only in these nucellar gametophytes.

Snyder et al. (1955) reported similar results from the study of a number of buffelgrass introductions in Puerto Rico. He suggested that Cenchrus ciliaris is not only apomictic but also pseudogamous, because normal seed set does not occur unless pollination and fertilisation of the endosperm takes place. Division of the aposporously produced eggs are apparently stimulated by development of the endosperm. It was observed in Cenchrus ciliaris and Panicum maximum in the 1950s (Warmke 1954, Snyder et al. 1955), and later in a number of other grasses. Snyder (1957) and Sherwood et al. (1980) considered buffelgrass to be a facultative apomict. Bray (1978) found that certain apomictic buffelgrass plants produced off-type progeny and reported that as evidence for facultative apomixis. However, in other apomictic genera off-type progeny 
can be produced by fertilisation of unreduced egg with a resultant increase in ploidy level (Gustafsson 1947).

Apomicts are valuable plants as Harlan and De Wet (1963) wrote that "natural apomicts are frequently more variable than sexual ones, more difficult to treat taxonomically, and are often among the most successful and palatable of all plants taxa and that the apomictic grasses can form an efficient genetic system, which can cross widely and escape the penalties of sterility".

\section{Cytological observations}

In order to characterise the species, cytological observations including chromosomal counts were carried-out. The chromosomal count in all plants was $2 n=34$. This is in agreement with several previous workers (Brown 1948, Darlington and Wylie 1955, Pienaar 1955, Gould 1956, De Lisle 1963, Mannetje and Jones 1992), but other chromosome numbers such as $2 n=32$ (Krishnaswamy 1940) and 36 (Brown 1948, De Wet and Anderson 1956, Gould 1958, Mannetje and Jones 1992) have been reported. Indeed it would appear that the euploid chromosome number is $2 \mathrm{n}=36$ and that Cenchrus ciliaris is an allotetraploid (Hacker 1995). However there is no indication of the diploid progenitors of such a tetraploid. Assuming that Cenchrus ciliaris is an allotetraploid. The chromosome number $2 n=34$ could be derived from $2 n=36$, by the loss of a single pair of chromosomes in this species (Brown 1948, Avdulow 1928). This in itself is not unusual in apomictic species.

Data on chromosomal associations and chiasma frequency at metaphase I are presented in Table 1. The behaviour of chromosomes at meiosis appeared somewhat irregular in all plants, showing univalents, trivalents and quadrivalents, in addition to normal bivalents at metaphase I of meiosis (Table 1, Figs. 3a, b). The number of univalents ranged from $0.10-0.48$, along with some trivalents at a low frequency (0.1). Quadrivalents were recorded in eight of the ten plants with frequency being much higher in plant 4 , in which the mean per cell was 1.00 and the frequency range per cell was zero to three (Table 1).

Two possible interpretations can be advanced for the presence of multivalents at metaphase I of meiosis in this material. In the first place, it could be the result of intragenomic chromosome translocation, which is not uncommon in apomictic species. The presence of a maximum of three quadrivalents in a cell in one plant would be indicative of three such events. While this is rather a high number it is not impossible as there is no meiotic (gamete) selection against such rearrangements in apomictics.

Table 1. Mean meiotic chromosomal configuration and chiasmata frequencies of PMCs in Cenchrus ciliaris L.

\begin{tabular}{|c|c|c|c|c|c|c|c|c|}
\hline \multirow{3}{*}{ Plant } & \multicolumn{8}{|c|}{ Chromosomal Configuration } \\
\hline & \multirow{2}{*}{ I (Univ.) } & \multicolumn{3}{|c|}{ II (Biv.) } & \multirow{2}{*}{ III (Triv.) } & \multicolumn{3}{|c|}{ IV (Quad.) } \\
\hline & & Ring & Rod & Total & & Mean & Range & Chiasmata \\
\hline 1. & 0.48 & 13.66 & 2.44 & 16.10 & 0.00 & 0.33 & $0-1$ & 31.00 \\
\hline 2. & 0.10 & 10.80 & 5.00 & 15.80 & 0.10 & 0.50 & $0-2$ & 28.60 \\
\hline 3. & 0.24 & 12.22 & 4.00 & 16.22 & 0.00 & 0.33 & $0-1$ & 29.55 \\
\hline 4. & 0.16 & 10.00 & 4.71 & 14.71 & 0.14 & 1.00 & $0-3$ & 27.57 \\
\hline 5. & 0.28 & 10.72 & 5.30 & 16.02 & 0.00 & 0.42 & $0-1$ & 25.42 \\
\hline 6. & 0.00 & 12.14 & 4.28 & 16.42 & 0.00 & 0.29 & $0-1$ & 29.57 \\
\hline 7. & 0.00 & 12.25 & 4.75 & 17.00 & 0.00 & 0.00 & $0-0$ & 26.75 \\
\hline 8. & 0.00 & 11.25 & 5.25 & 16.50 & 0.00 & 0.25 & $0-1$ & 28.50 \\
\hline 9. & 0.00 & 10.25 & 5.75 & 16.00 & 0.00 & 0.50 & $0-1$ & 27.00 \\
\hline 10. & 0.00 & 14.25 & 2.75 & 17.00 & 0.00 & 0.00 & $0-0$ & 31.25 \\
\hline
\end{tabular}

Average of 10 measurements in each case. 


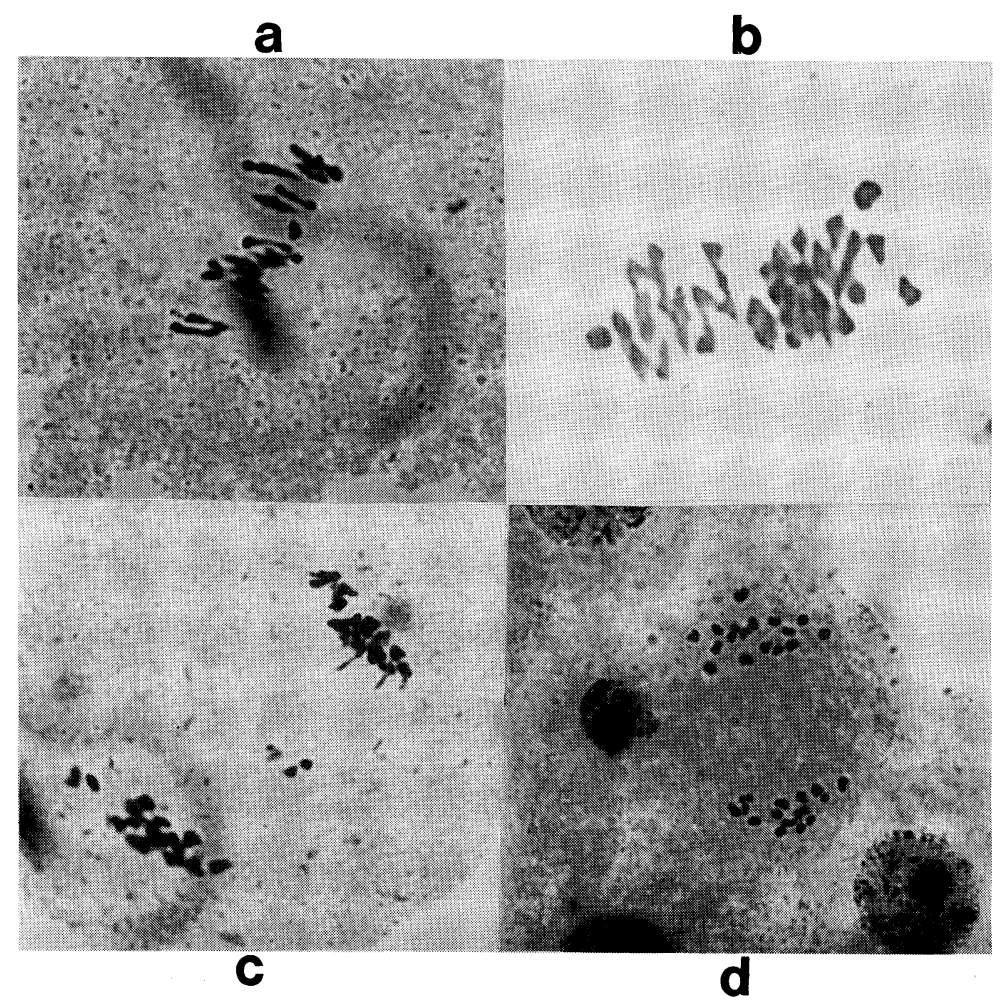

Fig. 3. (a-d): Chromosome association in Cenchrus ciliaris L. a. Metaphase I showing 1 Trivalent and 1 Univalent. b. Metaphase I showing 1 Quadrivalent and 2 Univalents. c. Anaphase I showing laggards. d. Anaphase I showing normal separation of the 34 chromosomes.

The second possibility is that the control of intergenomic chromosome association ( $\mathrm{Ph}$ system) is less than perfect and that homoeologous chromosome pairing and crossing over occurs very occasionally. In subsequent generations this would manifest itself as "homoeologous interchange" of segments with the four chromosomes of a set being partly homologous giving quadrivalents or trivalents at meiosis.

Implicit in this interpretation is that this population of Cenchrus ciliaris is either a facultative apomict or the occasional sexual mutant does occur. Rearrangements of this type could only be incorporated through sexual reproduction. This would support the suggestion made earlier that it is a facultative apomict (Snyder 1957, Bray 1978, Sherwood et al. 1980).

A few cells with lagging chromosomes were also seen at anaphase I of meiosis (Fig. 3c), although many cells showed normal separation of chromosomes (Fig. 3d). All these chromosomal irregularities discussed are indirectly associated with the apomictic phenomena of reproduction (Nath et al. 1970, Gustafsson 1946).

\section{Summary}

This paper gives the results of breeding system and cytological investigations on Cenchrus ciliaris L. a grass of District Rawalakot, Azad Kashmir-Pakistan. It is confirmed that Cenchrus ciliaris is apomict, probably a facultative apomict.

The meiotic results indicated that the chromosome pairing of this species was somewhat irregular, showing multivalents at metaphase I of meiosis. Cenchrus ciliaris is suggested to be allotetraploid with $2 n=34$. The chromosome number $2 n=34$ of this ecotype from Azad 
Kashmir-Pakistan, could be derived from $2 \mathrm{n}=36$, by the loss of a single pair of chromosome. It is concluded that all meiotic irregularities are indirectly associated with the apomictic phenomena of reproduction.

\section{Acknowledgement}

Thanks are due to the Royal Society of England for the award of this fellowship, which enabled me to undertake this research project at the Institute of Biological Sciences, University of Wales, Aberystwyth, UK.

I am thankful to Dr. Gareth M. Evans for the identification of District Rawalakot grasses, supervision and valuable suggestions, and to Mr. D. S. Fallding for technical assistance.

\section{References}

Avdulow, N. P. 1928. Karyo-systematische Untersuchungen der Familie Gramineen. All Union Cong. Bot. Moscow Jour. 65-67.

Bashaw, E. C. 1962. Apomixis and sexuality in buffelgrass. Crop Sci. 2: 412-415.

Bray, R. A. 1978. Evidence for facultative apomixis in Cenchrus ciliaris. Euphytica 27: 801-804.

Brown, W. V. 1948. A cytological study in the Gramineae. Amer. J. Botany 35: 382-396.

- and Emery, W. H. P. 1958. Apomixis in the Gramineae: Panicoideae. Amer. J. Botany 45, 253-263.

Cope, T. A. 1982. Poaceae. In E. Nasir and S. I. Ali (ed), "Flora of Pakistan" No. 143 Karachi, Uni. Press, Karachi, Pakistan.

Darlington, C. D. and Wylie, A. P. 1995. Chromosome Atlas of Flowering Plants. George Allen and Unwin, London.

De Lisle, D. G. 1963. Taxonomy and distribution of genus Cenchrus. Iowa State Jour. Sci. 37: 259-351.

De Wet, J. M. J. and Anderson, L. J. 1956. Chromosome numbers in Transvaal grasses. Cytologia 21, 1-10.

Evans, G. M. and Davies, E. W. 1985 . The genetics of meiotic chromosome pairing in Lolium $\times$ Lolium perenne tetraploids. Theor. Appl. Genetics 71: 185-192.

Fischer, W. D., Bashaw, E. C. and Holt, E. C. 1954. Evidence for apomixis in Pennisetum ciliare and Cenchrus setigerus. Agron. J. 46: 401-404.

Gould, F. W. 1956. Chromosome counts and cytotaxonomic notes on grasses of the tribe Andropogoneae. Amer. J. Botany 43, 395-404.

- 1958. Chromosome numbers in South-Western grasses. Amer. J. Botany 45: 757-767.

Gustafsson, A. 1946. Apomixis in higher plants. Part 1. The mechanism of apomixis. Lunds Uni. Asskrift N. F. 42: $1-66$.

- 1947. Apomixis in higher plants. Part 2. The causal aspect of apomixis. Lunds Uni. Asskrift N. F. 43: 71-179.

Hacker J. B. 1995. Tropical and subtropical grasses. Various Genera (Paniceae). "In Evolution of Crop Plants" 2nd Ed. Eds. J. Smartt and N. W. Simmonds. Longmans Scientific and Technical UK. pp. 229-235.

Harlan, J. R. and De Wet, J. M. J. 1963. Role of apomixis in the evolution of Bothriochloa-Dichanthium complex. Crop Sci. 3: 314-318.

Hartley, W. 1958. Study on the origin, evolution and distribution of the Gramineae II. The Paniceae, Austr. J. Bot. 6: 343-357.

Hutton, E. M. 1970. Australian research in pasture plants introduction and breeding. Proc. 11th Int. Grassland Congress. Surfers Paradise, Australia p. A1.

Jain, S. K. 1976. The evolution of inbreeding in plants. Annu. Rev. Ecol. Syst. 7: 469-495.

Johnson, B. L. and Hall, O. 1965. Analysis of phylogenetic affinity in the Triticinae by protein electrophoresis. Amer. J. Botany 52, 506-513.

Khan, C. M. A. 1970. Effect of clipping intensities on forage yield of (Cenchrus ciliaris) in Thal, Pakistan. Pak. J. For. 20: $75-87$.

Krishnaswamy, N. 1940. Untersuchungen zur Cytologie und Systematik der Gramineen. Beih. Bot. Centralbl. 60A: $1-56$.

Langer, R. H. M. and Hill, G. D. 1982. Agricultural Plants. Cambridge Uni. Press. Cambridge.

Mannetje, L. T. and Jones, R. M. 1992. Plant Resources of South-East Asia No. 4, Forages Pudoc Scientific Publisher, Wageningen.

Mehra, K. L. and Anderson, E. 1961. Character association analysis, its use in grass taxonomy. In Recent advances in Botany, Uni. Toronto Press, Toronto Canada. 
Mehra, P. N. and Remanandan, P. 1973. Cytological investigation on W. Himalaya Pooideae. Cytologia 38: $237-258$. Nath, J., Swaminathan, M. S. and Mehra, K. L. 1970. Cytological studies in tribe Paniceae (Gramineae). Cytologia 35: 111-131.

Neelam, A. and Narayan, R. K. G. 1994. Studies on back-cross progeny of Nicotiana rustica $\times$ Nicotiana tobaccum inter specific hybrids I. Cytological analysis. Cytologia 59: 377-384.

Pienaar, R. de V. 1955. The chromosome numbers of some indigenous South African and introduced Gramineae. 551570 in the "Grasses and Pastures of South Africa" Ed. Meredith D.

Sherwood, R. T., Young, B. A. and Bashaw, E. C. 1980. Facultative apomixis in buffelgrass. Crop Sci. 20: 375-379. Snyder, L. A., Hernandez, A. R. and Warmke, H. E. 1955. The mechanism of apomixis in Pennisetum ciliare. Bot. Gaz. 116: 209-211.

- 1957. Apomixis in Paspalum secans. Amer. J. Botany 44: 318-324.

Stebbins, G. L. 1956. Cytogenetics and evolution of the grass family. Amer. J. Bot. 43: 890-905.

Wajahatullah, M. K. 1994. The behaviour of meiotic chromosomes in Leek, A. porrum L. Cytologia 59: 333-338.

Wallace, A. J. and Callow, R. S. 1995. Meiotic variation in an intergenomic autopolyploid series. 1. Chiasma frequency. Genome 38: 122-132.

Warmke, H. E. 1954. Apomixis in Panicum maximum. Amer. J. Botany 41: 5-11.

Whyte, R. O., Moir, T. R. and Cooper, J. P. 1959. Grasses in Agriculture, FAO Agricultural studies, No. 42, FAO, Rome. 